\title{
Okul öncesi öğretmenlerinin fen öğretimine yönelik tutumlarının problem çözme becerilerini yordama gücü
}

\section{Predictive power of preschool teachers' attitudes towards science teaching for problem-solving skills}

\author{
Serpil Pekdoğan ${ }^{1}$
}

\begin{abstract}
Makale Geçmişi
Geliş : 22 Mayıs 2019

Düzeltme : 9 Temmuz 2020

Kabul : 25 Temmuz 2020
\end{abstract}

Makale Türü

Arastorma Makalesi
Article History

Received : 22 May 2019

Revised : 9 July 2020

Accepted : 25 July 2020

Article Type

Research Article

\begin{abstract}
Öz: Bu çalışmanın amacı okul öncesi öğretmenlerinin fen öğretimine yönelik tutumlarının problem çözme becerilerini yordama gücünü incelemektir. Çalışmada ilişkisel tarama modeli kullanılmıştır. Araștırmanın çalıșma grubunu 275 okul öncesi öğretmeni olușturmaktadır. Öğretmenlerin fen öğretimine yönelik tutumlarını ölçmek amacıyla Fen Bilimleri ve Fen Bilgisi Öğretimine Karşı Tutum Ölçeği (Moore ve Foy, 1999), problem çözme becerilerini ölçmek için ise Problem Çözme Envanteri (Heppner ve Peterson,1982) kullanılmıştır. Verilerin analizinde okul öncesi öğretmenlerinin fen öğretimine yönelik tutumları ve problem çözme becerilerine ilişkin betimsel istatistikler hesaplanmıs, fen öğretimine yönelik tutumun, problem çözme becerilerini yordamasına ilişkin veriler basit doğrusal regresyon eşitliğinde açıklanmıştır. Çalışmanın sonucunda okul öncesi öğretmenlerinin fen öğretimine yönelik tutumları ve problem çözme becerilerinin orta düzeyde olduğu görülürken, fen öğretimine yönelik tutumun problem çözme becerilerinin anlamlı bir yordayıcısı olduğu sonucuna ulaşılmıştır.
\end{abstract}

Anahtar Kelimeler: Okul Öncesi, Öğretmen, Fen Öğretimi, Problem Çözme Becerisi.

\begin{abstract}
The purpose of this study is to investigate the extent to which preschool teachers' attitudes towards science teaching predict their problem-solving skills. Correlational study is realized. The study group consisted of 257 preschool teachers. The Scientific Attitude Inventory (Moore \& Foy, 1999) was used to measure preschool teachers' attitudes towards science teaching and the Problem Solving Inventory (Heppner \& Peterson,1982) was used to measure preschool teachers' problem-solving skills. The data were analyzed using descriptive statistics. Simple linear regression was used to analyze the data on the prediction of scientific attitudes for problem-solving skills. The analysis results indicated that preschool teachers had a moderate level of scientific attitude and problem-solving skills and scientific attitude was a significant predictor of problem-solving skills.
\end{abstract}

Keywords: Preschool, Teacher, Science Teaching, Problem Solving Skills. 


\section{SUMMARY}

\section{Introduction}

A teacher who is a good role model for children and facilitates children's active engagement in science learning should also have good problem-solving skills. A teacher with advanced problem-solving skills helps children to be good problem solvers. D'Zurilla and Goldfried (1971) defined problem-solving as a comprehensive cognitive and behavioral process of choosing and deciding on an appropriate solution among a set of effective solutions. Research on problem-solving has shown that individuals differ in their approach to a problem and problem-solving skills. Individuals who perceive themselves as adequate in problem-solving are more assertive and academically successful (Şahin, Şahin \& Heppner, 1993). One of the main objectives of education is to help individuals to gain a system of thought that helps them solve potential life problems (Kuru, 2000). In preschool science education, teachers should care to help children to have alternative ways of thinking and different perspectives in order to promote their problem-solving skills (Tuğrul, 1993).

Davies and Howe (2003) noted that teachers' attitudes towards science teaching are based on their educational experiences and negative attitudes are reflected in children. Considering the development of problem-solving skills covered in science curricula, teachers are the second most influential people in children after family. Previous research has indicated that when teachers have a high level of problemsolving skills, they more frequently use these skill in teaching and by extension can promote children's problem-solving skills (Ceylan, Bıçakçı, Aral \& Gürsoy, 2012; Sarı \& Bozgeyikli, 2003). Thus, it is of importance to be informed of preschool teachers attitudes towards science teaching and to transform negative attitudes, if any, into positive ones. Additionally, it seems to be more helpful and effective to identify and transform negative attitudes towards science teaching not in the in-service period but in the pre-service period. Against this background, the purpose of this study is to investigate preschool teachers' attitudes towards science teaching and their problem-solving skills and to determine the extent to which preschool teachers' attitudes towards science teaching predict their problem-solving skills.

\section{Method}

The study planned in correlationa research aiming to investigate preschool teachers' attitudes towards science teaching and their problem-solving skills in terms of a set of variables.

The study group consisted of 257 preschool teachers working in several provinces of Turkey. Among the participants, $225(81.8 \%)$ were female and $50(18.2 \%)$ were male. 59 participants $(21.5 \%)$ had a professional experience of 1 to 5 years, 97 (35.3) had a professional experience of 6 to 10 years, 78 (28.4\%) had a professional experience of 11 to 14 years, and $41(14.9 \%)$ had a professional experience of 15 years and over. 
The data were collected using the Scientific Attitude Inventory (SAI) and the Problem Solving Inventory (PSI). The Scientific Attitude Inventory (SAI) was originally developed by Moore in 1973 and adapted to Turkish by Türkmen (1999). The test-retest reliabilityof the scale was found to be 0.79 . SAI is a 5-point Likert scale consisting of 60 items. The half of the items are about science and the other half about science teaching. In this study, Cronbach's alpha coefficient of the scale was found to be .78 .

Problem Solving Inventory (PSI) is an instrument that measures individuals' responses to problems they encounter in their daily lives. PSI was developed by Heppner and Peterson in 1982. PSI is a 6-point Likert scale consisting of three sub-scales including the confidence in problem-solving skills, personal control, and approach/avoidance. Cronbach's alpha coefficient of the scale was found to be .82 (Savaşır \& Şahin, 1997). Cronbach's alpha coefficient of PSI was found to be .79.

\section{Data Collection and Data Analysis}

The data were collected through online questionnaires and analyzed using SPPS Statistics V 20.0. First, descriptive statistics for preschool teachers' attitudes towards science teaching and problem-solving skills were calculated. Then, the assumption of linearity was tested through regression analysis and confirmed. The correlation between dependent and independent variables was explained in light of the results of simple linear regression analysis.

\section{Results and Discussion}

The preschool teachers' mean score was $X=63.42$ for the sub-scale attitudes towards science, $X=77.13$ for the sub-scale attitudes towards science teaching, and $\bar{X}=140$ for the total SAI. Türkmen (1999) reported that the possible score range was 150 to 30 for the sub-scale and 300 to 60 for the total scale. Accordingly, the preschool teachers' had a moderate level of scientific attitude. Considering the descriptive analysis results of preschool teachers' problem-solving skills, the preschool teachers' mean score was $X=8.06$ for the sub-scale confidence, $X=8.02$ for the sub-scale personal control, $X=73.91$ for the sub-scale approach/avoidance, and $X=130$ for the total PSI. The possible score range of PSI is 192 to 32 . Accordingly, the preschool teachers' also had a moderate level of problem-solving skills. A great volume of research (Dowdy, 2005; Özbey, 2006; Bahçeci Sansar, 2010; Akman, Veziroğlu, Alabay \& Aksoy, 2010; Van Aalderen-Smeets et al., 2012; Edwards \& Loveridge, 2011; Nilsson, 2015; Karaca, Aral \& Karaca, 2013) reported parallel results. It thus seems that teachers were good problem solvers during their university education and had positive scientific attitudes. It also seems that as teachers' professional experience increases, they become more professional in preschool science teaching, use different methods and techniques, better identify the group of children, and design more functional and student-centered teaching plans. Thanks to advanced technology, today's teachers are able to easily research, inquire and access different sources of information. Thus, technological facilities and easy access to information 
contribute to the development of teachers' scientific attitudes and problem-solving skills. Additionally, it seems that the preschool teachers' previous (pre-service) scientific education and problems they encountered in this education had an effect on their scientific attitudes.

The analysis results indicated that the preschool teachers' scientific attitudes significantly predicted their problem-solving skills and there was a positive correlation between the preschool teachers' scientific attitudes and problem-solving skills $\left(\mathrm{F}_{(1,273)}=298.390, \mathrm{p}<.05\right)$. Accordingly, it was seen that preschool teachers' scientific attitude was a significant predictor of problem-solving skills. Considering the regression coefficients, there was a positive correlation between scientific attitudes and problem-solving skills. Mattern and Schau (2002) argued that a classroom environment created by a teacher with positive scientific attitudes is more efficient. Problem-solving skills are among the most effective ways to achieve general objectives in an effective classroom environment (Krug et al., 2015) since there is a need for preschool teachers who are able to think, question, investigate and address problems from different perspectives, that is, have good problem-solving skills in order to achieve effective science teaching. Preschool teachers' pre-service science education, more accessible teaching materials and contents thanks to technological developments, and the growing interest and curiosity of children of the new generation may have contributed to preschool teachers' positive scientific attitudes and good problem-solving skills. An increase in the volume of research on preschool teachers' scientific attitudes and problem-solving skills will contribute to making a more general assessment of this issue. Further research can investigate the development of children's problem-solving skills through preschool science activities. Experimental research can be conducted to examine the effect of science activities integrated with different types of activities on teachers' interest, attitudes, and perceptions. 


\section{GÍRİ̧̧}

Çocuklar doğal bir merak ve keşfetme güdüsüyle dünyaya gelmektedirler. Günlük yaşam deneyimleri içerisinde çocuklar dünyayı tanıma, anlama ve algılamaya yönelik birçok firsatla karşılaşmaktadırlar. Okul öncesi dönemde de çocuklar bilgiyi arama, anlamlandırma ve yeniden yapılandırma süreci içerisindedirler. Öğretmenin rehberliğinde ve çocuğun sorumluluk alarak bitki yetiştirme, hayvan besleme, deneyler yapma, alan gezileri, koleksiyonları içeren fen etkinlikleri, çocukların gelişim alanlarına katkı sağlamanın yanı sıra hayata olan bakış açıları üzerinde olumlu etkilere sahiptir. Bu süreçte çocuklar soru sorma, araştırma, inceleme, deneme ve problem çözme becerilerini kullanırlar (Aral vd., 2003; Boran, 2005; Oğuzkan ve Oral, 1995; Uyanık Balat, 2011).

Çocukların öğrenmeleri için sıcak bir ortam yaratan öğretmenin, fen eğitiminde olumlu tutum sergilemek için gerekli yetenek ve rollere de sahip olması gerekmektedir (Harlan ve Rivkin, 2000). Bu noktada duyuşsal alan özellikleri karşımıza çıkmaktadır (Simpson vd., 1994). Duyuşsal alan özellikleri; ilgiler, değerler, eğilimler ve en önemlisi de tutumlar ile ilgilidir. Tutum kavramı bireyin herhangi bir nesne, olay veya duruma karşı olumlu ya da olumsuz davranış sergilemesine neden olan önemli bir faktör olarak tanımlanmaktadır (Durdukoca, 2015). Fen bilimlerini sevme ya da hoşlanmama gibi özel duyguların belirlenmesine yönelik tutumlar ise fen öğretimine yönelik tutum olarak adlandırılmaktadır (Shrigley vd., 1988; Simpson ve ark., 1994). Öğretmenlerin fen öğretimine yönelik olumlu tutumlar sergilemeleri, çocukların da fen bilimlerine karşı olumlu duygular beslemesi ve çeşitli deneyimler kazanmaları açısından önemlidir. Araştırmalar bir duruma yönelik tutumun erken çocukluk döneminde edinildiğini kolayca değişmediğini belirtmektedir (Kocabaş, 1997). Bu bağlamda çocukların fene yönelik kavramları imgelendirmeleri ve fen bilimlerini erken yaşlarda sevmeleri amacıyla okul öncesi dönemde fen öğretiminin etkili bir şekilde yapılası gerekmektedir. Okul öncesi dönemde fen eğitiminin amacı çocuğun tahmin ve gözlemler sonucu yorumlar yapabilmesidir. Çocukların neleri yapabildikleri konusunda öğretmenlerin bilgi sahibi olması da fen eğitiminin etkinliğini arttırmaktadır. Çocukların ilgileri ve yeteneklerinin farklılığı öğretmen tarafindan dikkate alınmalı ve öğrenme yaşantıları çocuğa görelik ilkesi dikkate alınarak planlamalıdır. İyi bir fen eğitimi çocuğun aktif olarak katıldığı, çocuk merkezli uygulamalardan oluşmaktadır. Öğretmen çocukların araştırma, sorgulama, gözlemleme, ölçme ve değerlendirme gibi bilimsel süreç becerilerini geliştirecek çalışmalara yer vermelidir (Arnas, 2002; Kallery ve Psillos, 2001; Lind, 1999; Oğuzkan ve Oral, 2003). Öğretmen; çocuklarda merak ve ilgi uyandırdığında, çocuklarında bilimsel çalışmalara olan ilgisi artmaktadır. Çünkü çocuklar sevdikleri ve hoşlandıkları kişilerin tavırlarını model almaktadırlar (Hewett, 2001). 
Fen öğretiminde çocukların sürece aktif katılımını sağlayan ve çocuklara iyi bir rol model olan öğretmen aynı zamanda iyi bir problem çözme becerisine de sahip olmalıdır. Problem çözme becerisi gelişmiş olan öğretmen, çocukların da iyi birer problem çözücü olmalarına katkı sağlamaktadır. Öğrenme yaşantılarında çocuklar model alarak öğrenme sürecini fazlaca benimsemektedirler. D'Zurilla ve Goldfried, (1971), problem çözmeyi, etkili çözüm yollarının seçilmesi sonucunda, uygun çözüm yolunu seçme ve karar vermeyi içeren zihinsel ve davranışsal süreç olarak tanımlamaktadırlar. Problem çözme davranış farklı yetenek ve becerilerin yanı sırsa bireyin çevresine uyum sağlarken yeni yollar bulabilmesi için problem çözme becerilerinin geliştirilmesini de gerektirmektedir (De Bono, 2000). Problem çözme alanındaki araştırmalar, bireylerin problem çözme becerilerinin birbirinden farklı olduğunu göstermektedir. Problem çözme sürecinde kendisini yeterli algılayan bireylerin daha girişken ve akademik olarak daha başarılı oldukları belirtilmektedir (Şahin, Şahin ve Heppner, 1993). Eğitim sürecinin temel özelliklerinden birisi de bireyi hayatta karşılaşabilecekleri problemleri çözebilmesinde ona yardımcı olacak düşünce sistematiğini kazandırmaktır (Kuru, 2000). Okul öncesi fen eğitiminde de öğretmen çocukların problem çözme becerilerini geliştirmek için olaylara farklı açılardan bakmalarını sağlayarak, alternatif düşünme yolları kazandırmaya önem vermelidir (Tuğrul, 1993). $\mathrm{Bu}$ noktada okul öncesi öğretmenlerinin farklı yöntem ve stratejiler kullanarak problemleri çözmeleri, çocuklar içinde iyi bir rol model olmaktadır.

Davies ve Howe (2003); öğretmenlerin fen öğretimine yönelik olumsuz tutumların çocuklara yansıyacağını belirtmişlerdir. Fen öğretiminin içerisinde yer alan problem çözme becerilerinin de gelişmesinde, çocukların üzerinde en etkili olan kişiler aileden sonra öğretmenlerdir. Yapılan çeşitli araştırmalar, öğretmenlerin problem çözme becerilerinin yüksek olmasının, bu becerinin eğitimde daha çok kullanılacağı ve çocukların problem çözme becerilerini arttırabileceğini ortaya koymaktadır (Ceylan vd., 2012; Sarı ve Bozgeyikli, 2003). Bu sebeplerden ötürü, okul öncesi öğretmenlerinin fene yönelik tutumlarının tespiti ve olumlu yönde değiştirilmesi önemlidir. Tutum değiştirme sürecinin öğretmenliğe başladıktan sonra değil, daha önceki eğitimleri sürecinde ele alınması daha kalıcı ve istendik davranışların oluşmasına neden olacaktır. Ayrıca alan yazın incelendiğinde öğretmenlerin fen eğitimine yönelik tutumları ve problem çözme becerilerinin psikolojik sağlamlık, karar verme becerileri, öz yeterlik becerileri, bilimsel süreç becerilerini kullanma düzeyleri, kullanılan yöntemler gibi farklı değişkenlerle ilişkilendirilerek incelendiği görülmektedir (Baysal, Arkan ve Demirbaş, 2011; Huang ve Flores, 2011; Kaya, 2008; ; Kefi, Çeliköz ve Erişen, 2013; Kesgin, 2006; Sı̆̆ırtmaç ve Özbek, 2011; Şenler, Karışan ve Bilican, 2017; Udeani ve Adeyemo, 2011). Bu çalışma, okul öncesi öğretmenlerinin fen öğretimine yönelik tutumları ile problem çözme becerilerini ele alan bir araştırmanın olmaması ve 
çalışmanın alan yazında bu konuda çalışma yapacak araştırmacılara ve eğitimcilere destek sağlaması açısından önem taşımaktadır.

Araştırmanın amacı okul öncesi öğretmenlerinin fen öğretimine yönelik tutumlan ile problem çözme becerileri düzeylerini incelemek ve okul öncesi öğretmenlerinin fen öğretimine yönelik tutumlarının, problem çözme becerilerini ne düzeyde yordadığını belirlemektir. Bu genel amaç doğrultusunda araştırmada, aşağıdaki sorulara yanıt aranmıştır;

1. Okul Öncesi öğretmenlerinin fen öğretimine yönelik tutumları ve problem çözme becerileri ne düzeydedir?

2. Okul öncesi öğretmenlerinin fen öğretimine yönelik tutumları problem çözme becerilerini ne düzeyde yordamaktadır?

\section{YÖNTEM}

\section{Araştırmanın Modeli}

Araştırma, okul öncesi öğretmenlerinin fen öğretimine yönelik tutumları ve problem çözme becerilerini farklı değişkenler açısından incelemeyi amaçladığından, betimsel tarama modellerinden ilişkisel tarama modeli kullanılmıstır. Bu model, iki veya daha fazla değişken arasındaki değişimin varlığını ve derecesini belirlemeyi amaçlamaktadır (Karasar,2009).

\section{Çalışma Grubu}

Araştırmanın çalışma grubunu Türkiye'nin çeşitli illerinde (Amasya, Samsun, Çorum, Şanlı Urfa, Muş, Malatya) görev yapan 275 okul öncesi öğretmeni oluşturmaktadır. Örneklem seçiminde basit olasılıklı örnekleme yöntemi kullanılmışır. Bu örnekleme yönteminde katılımcılar araştırma sürecine dahil olabilme açısından eşit şansa sahiptirler ve rastgele seçilirler (Ekiz, 2013). Araştırmada kullanılan ölçme araçları çevrimiçi doküman şeklinde öğretmenlere ulaştırılmıştır. Çalışma grubunda yer alan katılımcıların, 225’i (\%81,8) kadın, 50’si (\%18,2) erkektir. Katılımciların 59’u (\% 21.5) 1-5 y1l, 97’si (\%35.3) 6-10 yıl, 78’i (28.4) 11-15 yll, 41’i (14.9) 15 yll ve üzeri mesleki deneyime sahiptirler.

\section{Veri Toplama Araçları}

Araştırmada veri toplama aracı olarak Fen Bilimleri ve Fen Bilgisi Öğretimine Karşı Tutum Ölçeği ve Problem Çözme Becerileri Envanteri kullanılmıştır. 
Fen Bilimleri ve Fen Bilgisi Öğretimine Karşı Tutum Ölçeği: Araştırmada kullanılan Fen Bilimleri ve Fen Bilgisi Öğretimine Karşı Tutum Ölçeği ilk defa Moore tarafindan 1973 yılında oluşturulmuş, 1997 yilında Moore ve Foy tarafindan Fen Bilgisi Öğretimi Tutum Ölçeği II olarak güncellenmiştir. Fen Bilgisi Öğretimi Tutum Ölçeği II ülkemizde Türkmen (1999) tarafindan Türkçeye uyarlanmış, tekrar-test uygulamaları sonucunda ölçeğin güvenirliği .79 bulunmuştur. 5’li likert türü olan ölçme aracında, yer alan ifadeler fen bilimleri ve fen bilgisi öğretimiyle ilgilidir. Ölçme aracından alınabilecek puan aralı̆̆1 300-60 arasında, alt boyutlarda ise 150 ile 30' dur. Bu çalışmada ise ölçeğin Cronbach Alfa güvenirlik katsayısı, .78 olarak bulunmuştur.

Problem Çözme Envanteri: Bireylerin günlük yaşantılarında karşılaştıkları problemlere verdikleri tepkileri ölçen bir araçtır. Heppner ve Peterson tarafından 1982 yllında geliştirilmiştir. Taylan (1990) ve Şahin, Şahin ve Heppner (1993) tarafından Türkçe uyarlaması yapılmıştır. 6’lı likert tipi olan ölçme aracının, Problem çözme yeteneğine güven, Kişisel kontrol ve Yaklaşmakaçınma alt ölçekleri bulunmaktadır. Ölçeğin, Cronbach Alpha güvenirlik katsayısı .82 olarak bulunmuştur (Savaşır, Şahin, 1997). Ölçme aracından alınabilecek en yükssek ve en düşük puan 192-32 arasındadır. Bu çalışmada ise Problem Çözme Envanterinin cronbach alfa güvenirlik katsayısı .79 bulunmuştur.

\section{Verilerin Toplanması ve Analizi}

Veriler toplanmadan önce çevrimiçi olarak öğretmenlere onam formu gönderilmiş ve çalışmaya katılmada gönüllük esas alınmıştır. Çevrimiçi doküman yoluyla toplanan veriler (e-mail ve online anketler), SPPS 20.0 programına işlendikten sonra, öncelikle okul öncesi öğretmenlerinin fen öğretimine yönelik tutumları ve problem çözme becerilerine ilişkin betimsel istatistikler hesaplanmıştır, daha sonra verilerin regresyon analizinin "doğrusallık” varsayımlarını karşıladığı görülmüştür. Bu bulgular ışığında çalışmada, bağımlı ve bağımsız değişkenler arasındaki ilişki basit doğrusal regresyon analizi eşitliğinde açıklanmaya çalışılmıştır. Standardize tahmini değerler ve sapmalar aşağıda sunulmuştur (Şekil 1). 


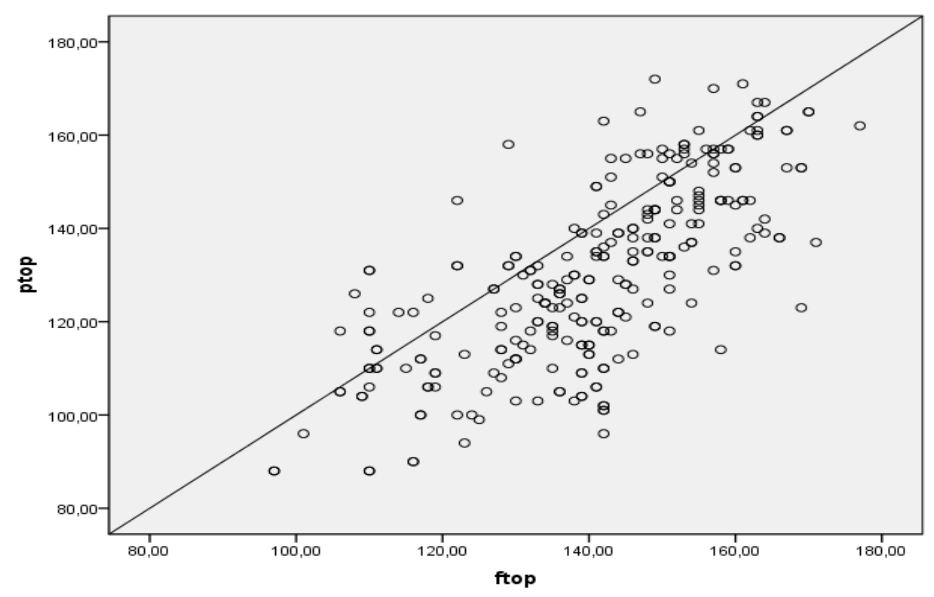

Şekil 1. Standardize tahmini değerler ve sapmalar

\section{BULGULAR}

Bu kısımda okul öncesi öğretmenlerini fen öğretimine yönelik tutum düzeyleri, problem çözme beceri düzeyleri ve fen öğretiminin problem çözme becerilerini yordamasına ilişkin bulgular yer almaktadır.

Tablo 1. Okul öncesi öğretmenlerinin fen öğretimine yönelik tutumlarına ilişkin betimsel istatistikler

\begin{tabular}{llll}
\hline Değişken & $\mathrm{n}$ & $\mathrm{X}$ & ss \\
\hline Fen Bilimleri & 275 & 63.42 & 7.78 \\
Fen bilgisi öğretimi & 275 & 77.13 & 9.94 \\
Toplam & 275 & 140.56 & 16.18 \\
\hline
\end{tabular}

Tabloda yer alan betimsel istatistik bulguları incelendiğinde okul öncesi öğretmenlerinin, fen bilimleri alt ölçeğinden aldıkları ortalama puanın $X=63.42$, fen bilgisi öğretimi alt ölçeğinden aldıkları ortalama puanın $X=77.13$ ve ölçme aracının toplamından aldıkları ortalama puanın $\bar{X}=140$ puan aldıkları görülmektedir. Türkmen (1999), ölçme aracının alt boyutlarından alınabilecek en yüksek düşük puan aralığının 150-30, ölçme aracının tamamından ise alınabilecek en yüksek düşük puan aralığının 300-60 olduğunu belirtmektedir. Bu bulgular 1şığında okul öncesi öğretmenlerinin fen öğretimine yönelik tutumlarının orta düzeyde olduğu söylenebilir.

Tablo 2. Okul öncesi öğretmenlerinin problem çözme beceri düzeylerine ilişkin betimsel istatistikler 


\begin{tabular}{llll}
\hline Değişken & $\mathrm{n}$ & $\mathrm{X}$ & ss \\
\hline PÇYG & 275 & 38.06 & 9.48 \\
KK & 275 & 18.02 & 5.15 \\
YK & 275 & 73.91 & 10.30 \\
Toplam & 275 & 130.0 & 19.21 \\
\hline
\end{tabular}

Okul öncesi öğretmenlerinin problem çözme becerilerine yönelik betimsel istatistikler incelendiğinde, problem çözme yeteneğine güven alt boyutundan alınan ortalama puanın $X=$ 38.06, kişisel kontrol alt ölçeğinden alınan ortalama puanın $X=18.02$, yaklaşma kaçınma alt ölçeğinden alınan ortalama puanın $X=73.91$ ve problem çözme envanterinin tamamından alınan ortalama puanın $X=130$ olduğu görülmektedir. Ölçme aracından alınabilecek en yüksek düşük puan aralığ1 192-32 arasındadır. Bu bulgular ışığında öğretmenlerin problem çözme becerilerinin orta düzeyde olduğu söylenebilir.

Okul öncesi öğretmenlerinin fen öğretimine yönelik tutumlarının, problem çözme becerilerini yordama gücünü ortaya koymak amacıyla yapılan basit doğrusal regresyon sonuçları Tablo 3'de verilmiştir.

Tablo 3. Okul öncesi öğretmenlerinin problem çözme becerilerini yordanmasına ilişkin basit doğrusal regresyon sonuçları

\begin{tabular}{llcc}
\hline Yordayıcı Değissken & $\beta$ & Yordama Gücü & Açıllanan Varyans $\left(\mathrm{R}^{2}\right)$ \\
\hline Fen öğretimine Yönelik Tutum & .723 & .723 & .522 \\
\hline
\end{tabular}

Tablo 3 incelendiğinde okul öncesi öğretmenlerinde fen öğretimine yönelik tutumun, problem çözme becerilerindeki varyansın \%52’sini açıkladığı görülmektedir. Basit doğrusal regresyon analizine ilişkin varyans analizi sonuçları aşağıdaki tabloda belirtilmiştir.

Tablo 4. Okul öncesi öğretmenlerinin problem çözme becerilerinin yordanmasına ilişkin varyans analizi sonuçları

\begin{tabular}{llllll}
\hline Varyans Kaynağ1 & $\begin{array}{l}\text { Kareler } \\
\text { Toplam1 }\end{array}$ & sd & $\begin{array}{l}\text { Kareler } \\
\text { Ortalamas1 }\end{array}$ & F & P \\
\hline Regresyon & 52813.464 & 1 & 52813.464 & 298.390 & .000 \\
Artık (Residual) & 48319.532 & 273 & 176.995 & \\
\hline
\end{tabular}

Tablo 4 incelendiğinde, basit doğrusal regresyon analizinde elde edilen yordama gücünün anlamlı düzeyde olduğu görülmektedir $\left(\mathrm{F}_{(1,273)}=298.390, \mathrm{p}<, 05\right)$. Bu bulgular sonucunda, okul öncesi öğretmenlerinin fen öğretimine yönelik tutumlarının, problem çözme becerilerinin anlamlı bir yordayıcısı olduğu söylenebilir. Regresyon katsayıları incelendiğinde, okul öncesi öğretmenlerinin bilimsel tutumları ile problem çözme becerileri arasında pozitif bir ilişkinin olduğu görülmektedir. 


\section{SONUÇ ve TARTIŞMA}

İyi bir öğretim kendini tanıma, yönlendirme, karar verme, eleştirel düşünme, eğitim araştırmaları ve uygulamaları ile tanımlanmaktadır. Öğretmenden beklenen ise eğitim sürecinde; öğretim yöntem ve tekniklerine ilişkin bilgi, beceri, eleştirel düşünme, problem çözme, öğrencilerin gelişim süreci ve onların öğrenmelerine ilişkin bilgi, beceri, tutum ve iletişim becerilerine sahip olmalarıdır (Yeşilyaprak, 2002). Öğretmenliğin en etkili ve en önemli olduğu ylllar olan okul öncesi dönem, çocukların nesne ve olaylar hakkındaki sorulara cevap aramak için gözlemlerde bulunduğu, bilgi ve becerilerinin temellerinin atıldığ1 ve ilk fen kavramlarının oluştuğu dönemdir (Martin,2000; Davies ve Howe, 2003). Bu sebepten dolayı birçok araştırmacı fen eğitiminin okul öncesi dönemde başlaması gerektiğini belirtmektedir (Kallery, 2004). Fen eğitiminde en önemli noktalardan birisi çocuğun fene olan ilgilisini desteklemek adına öğretmenin fen öğretimine yönelik tutumu ve çocuğun feni anlamasını sağlayacak olan problem çözme becerileridir. $\mathrm{Bu}$ bağlamda çalışmada ilk olarak okul öncesi öğretmenlerinin fen öğretimine yönelik tutum düzeyleri ve problem çözme becerileri düzeyleri incelenmiştir. Okul öncesi öğretmenlerinin fen öğretimine yönelik tutumları ve problem çözme becerilerinin orta düzeyde olduğu sonucuna ulaşılmıştır. Yapılan bir çok araştırmada da Akman ve diğerleri (2010); Bahçeci Sansar (2010); Dowdy, (2005), Özbey (2006); Edwards ve Loveridge, 2011; Van Aalderen-Smeets ve diğerleri, (2012); Nilsson (2015) ; Karaca, Aral ve Karaca (2013) benzer sonuçlara ulaşılmıştır. Bu durum öğretmenlerin üniversite eğitimi süresince iyi bir problem çözücü olduklarını ve fen öğretimine yönelik olumlu tutum içerisinde olduklarının ve öğretmenlerin meslekle ilgili tecrübeleri arttıkça, okul öncesi dönemde fen öğretimini daha profesyonel yapmaları, farklı yöntem ve teknikler kullanmaları, çocuk grubunu daha iyi tanımaları ve çocukları merkeze alan daha işlevsel eğitim programları hazırlamaları ile açıklanabilir.

Günümüz öğretmenleri gelişen teknolojiyle birlikte farklı bilgi kaynaklarına kolaylıkla ulaşmakta, araştırma yapmakta ve sorgulamaktadırlar. Bu uygulamaların hepsi öğretmenlerin fen öğretimine yönelik tutumları ve problem çözme becerilerinin gelişmesinde etkili olmaktadır. Ayrıca okul öncesi öğretmenlerinin geçmiş eğitim yaşantılarında, fen eğitimi almaları ve bu süreçte karşılaştıkları problemler, bu duruma yaklaşımları da söz konusu becerilerin gelişmesi üzerinde etkili olmuş olabilir. Hamurcu (2006) tarafından yapılan araştırmada okul öncesi öğretmenlerinin fen eğitimi dersi almadan önceki ve aldıktan sonraki tutumları arasında olumlu yönde farklılık olduğu görülmüştür. Çamlıbel Çakmak’ın (2006), araştırmasında okul öncesi 4.sınıf öğrencilerinin fene yönelik olumlu tutumlarının fan başarılarını artırdığı bulgusuna ulaşılmıştır. Araştırmalar incelendiğinde okul öncesi öğretmenlerinin lisans eğitimi boyunca fen eğitimine yönelik dersler 
almaları, fene yönelik tutumlarının olumlu yönde değişmesine neden olmuştur. Yapılan araştırmalar, söz konusu çalışmanın bulgularını destekler niteliktedir.

Eğitimin problem çözmeye dayalı olması çocukların daha çok deneyim kazanmasını, buna bağlı olarak da onların daha iyi problem çözücüler olmasını sağlamaktadır. Çocuklarda problem çözme becerilerinin gelişimi küçük yaşlardan itibaren başlamaktadır. Merak ve keşif duygusu içerisinde olan çocuklar, günlük yaşamlarında çeşitli problem durumlarıyla karşılaşmakta ve bu problemlere çözüm yolları aramaktadırlar. Özellikle okul öncesi dönemde üst düzeye çıkan problem çözme potansiyeli, öğretmenin çocuklara eğitimde problem çözücü olarak rol model olması ve farklı uyarıcılarla bütünleştirilmiş fen etkinlikleri uygulamaları yapması çocukların bu potansiyellerini daha iyi kullanmalarına katkı sağlayacaktır. Doksanlı yıllardan itibaren öğretmenlerin öğretme stillerine yönelik bilgi ve inançları araştırılmaya başlanmıştır, bu noktada pedagojik içerik bilgisi fen öğretiminde önemli bir dönüm noktası olmuştur (Doyle, 1990).Fen öğretiminde Grossman modeli pedagojik içerik bilgisi; konu bilgisi, öğrencinin kavram bilgisi, müfredat bilgisi ve eğitici stratejiler bilgisi olmak üzere 4 kategoride açıklanmaktadır (Grossman, 1990). Öğretmenlerin fen öğretimine yönelik tutumları, inançları, bilgi düzeyleri, fen içeriğindeki konulara hâkimiyeti, öğretme metotları, problem çözme becerileri fen öğretiminde önemli bir rol oynamıştır. Okul öncesi öğretmenlerinin fen öğretiminde yaşadıkları zorlukları ele alan bir araştırmada Appleton (2003), öğretmenlerin fen öğretiminde materyal temininde sıkıntı yaşadıkları, içerik konusunda yeterli bilgi sahibi olmadıkları ve bu durumun onlarda fen öğretimine yönelik olumsuz tutum geliştirdiğine neden olduğu sonucuna ulaşmıştır. Kallery (2004), Seefeldt ve Galper (2002); çalışmasında okul öncesi öğretmenlerinin, fen öğretiminde çocukların problem çözme becerilerini destekleyemediklerini, bunun nedeninin ise öğretmenlerin fen öğretimine yönelik iyi bir eğitim almamış olmaları, çalıştıkları sınıf alanının yetersiz olması ve fen öğretimine yönelik kaynak eksikliği, bilgi eksikliği ve uygulamalardaki sorunlar olduğunu belirtmişlerdir. Okul öncesi öğretmenlerinin bu eksikliklerinden dolayı yaptıkları fen eğitimleri çocuklarda kavram yanılgılarına neden olduğu belirtilmiştir. Astronomi, iklim, hava durumu, ölçüm, sabitlik, batma ve yüzme gibi konularda çocukların kavram yanılgılarının ortaya çıktı̆̆1 yapılan araştırmalarda belirtilmiştir (Garbett, 2003; Kallery, 2004).

Fen öğretimindeki bu tür eksiklikler ilerleyen yıllarda araştırmacıların dikkatini çekmiştir ve okul öncesi öğretmenlerinin eksikliklerini gidermek amaciyla eğitim programları uygulamaya başlamışlardır. Eğitim programlarında, çocuklara fen öğretiminde hangi içeriklerin, nasıl öğretilmesi gerektiği, kavram yanılgılarının nasıl önleneceği, fen öğretiminin yapılandırılması, fen öğretiminin doğası, gibi içerikler yer almıştır. Bu programlar zaman zaman tekrarlanarak, okul 
öncesi öğretmenlerinin fene yönelik tutumlarının dolayısıyla problem çözme becerilerinin zamanla geliştirilmesi sağlanmıştır (Liang, 2009).Bu tür gelişimlerin günümüzde etkisinin devamlılığını sınamak amacıyla araştırmada okul öncesi öğretmenlerinin fen öğretimine yönelik tutumları problem çözme becerilerini yordamakta mıdır? sorusuna yanıt aranmıştır. Bulgular okul öncesi öğretmenlerinin fene yönelik tutumlarının problem çözme becerilerinin anlamlı bir yordayıcısı olduğunu, fene yönelik tutumları ile problem çözme becerileri arasında olumlu bir ilişki olduğunu göstermiştir. Mattern ve Schau, (2002); fen öğretimine yönelik olumlu tutum içerisinde olan öğretmenlerin eğitim öğretim sürecinde daha etkili olduklarını belirtmektedirler. Sınıf ortamlarının da etkili öğretim yapılabilmesi ve belirlenen hedeflere ulaşmada problem çözme becerilerini önemi göz ardı edilemez (Krug vd., 2015). Çünkü etkili bir fen öğretiminin yapılabilmesi için düşünen, sorgulayan ve araştıran, sorunlara farklı açıdan bakabilen kısacası problem çözme becerileri gelişmiş okul öncesi öğretmenlerine ihtiyaç vardır.

Son yıllarda öğretmen adaylarının üniversite eğitimlerinde fen öğretimine yönelik aldıkları eğitimler, gelişen teknoloji ile birlikte öğretim materyalleri ve içeriklere daha kolay ulaşılabilir olması, yeni nesil çocuk profilinin uyarıcı fazlalığından dolayı artan merakı, öğretmenlerin fen öğretimine yönelik tutumlarının daha olumlu yönde olması ve buna bağlı olarak problem çözme becerilerinin gelişmesine olanak sağlamış olabilir. Alan yazında okul öncesi öğretmenlerinin fen öğretimine yönelik tutumları ve problem çözme becerilerini konu alan araştırmaların farklı örneklem grupları ve farklı konuları merkeze alarak bu konuda derinlemesine değerlendirmenin yapılmasına olanak sağlayacaktır. Okul öncesi öğretmenlerinin yaptıkları fen etkinliklerinde çocukların problem çözme becerilerinin gelişimine yönelik araştırmalar yapılabilir. Fen etkinlikleri farklı etkinlik türleri ile bütünleştirilerek, öğretmenlerin ilgi, tutum ve alg1 gelişimleri üzerindeki etkisini incelemek adına deneysel çalışmalar yapılabilir.

\section{KAYNAKÇA}

Aktaş Arnas, Y. (2002). Okul öncesi dönemde fen eğitiminin amaçlant. Çocuk Gelişimi ve Ë̆itim Dergisi, 1(7), 1-7.

Appleton, K. (2003). How do beginning primary school teachers cope with science?.Toward an understanding of science teaching practice.Research in Science Education, 33, 1-25.

Baysal, Z. N., Arkan, K. \& Demirbaş, B. (2011, Mayıs ). Sinıf ögretmenlerinin psikolojïk dayanıklullklar ile ögrencilerinin problem çözme becerileri arasindaki ilişkinin incelenmesi. 10. Ulusal Sınıf Öğretmenliği Eğitimi Sempozyumu, Sivas, Cumhuriyet Üniversitesi.

Ceylan, R., Yıldız Bıçakçı, M., Aral, N., \& Gürsoy, F. (2012). Okul öncesi eğitim kurumunda çalışan öğretmenlerin problem çözme becerilerinin incelenmesi. Trakya Üniversitesi Sosyal Bilimler Enstitüsï Dergisi, 14(1), 85-98. 
Chin, C. (2005). First year preservice teachers in Taiwan do they enter the teacher program with satisfactory scientific literacy and attitudes toward science?.International Journal of Science Education, 27(13), 1549-1570.

Çamlıbel Çakmak, Ö. (2006). Okul öncesi ögretmen adaylarnm fene ve fen ögretimine yönelik tutumlar ile baæı fen kavramlarm anlama düzeyleri arasındaki ilişkinin incelenmesi. Yayımlanmamış Yüksek Lisans Tezi, Abant İzzet Baysal Üniversitesi, Bolu.

Davies,D. \& Howe, A., (2003). Teaching science and design and technology in the early years. London: David Fulton Publishers.

Demirbaş, M. \& Yağbasan, R. (2006).Fen bilgisi öğretiminde bilimsel tutumların işlevsel önemi ve bilimsel tutum ölçeğinin Türkçeye uyarlama çalışması.Uludağ Üniversitesi Eğitim Fakültesi Dergisi, 19(2), 271-299.

Dowdy, J. T. (2005).Relationship between teachers' college science preparation and their attitudes toward science.Unpublished doctoral dissertation, Texas A\&M University-Commerce.

Doyle, W. (1990).Themes in teacher education research.In W. R. Houston, M. Haberman, \& J. Sikula (Eds.), Handbook of research on teacher education (pp. 3-24). New York: Macmillan Pub. Co.

Durdukoca, Ş.F. (2015). Özel eğitim dersine yönelik tutum ölçeğinin geliştirilmesi. Turkishstudies, 10 (11), 651-666.

Edwards, K.,\& Loveridge, J. (2011). The inside story: Looking into early childhood teachers' support of children's scientific learning. Australasian Journal of Early Childhood, 36(2), 28-36.

Garbett, D. (2003). Science education in early childhood teacher education: Putting forward a case to enhance student teachers confidence and competence. Research in science education, 33, 467-481.

Grossman, P.L. (1990). The making of a teacher. Teacher knowledge and teacher education. New York: Teacher College Press.

Hamurcu, H. (2006, Eylül).Okul öncesi ögretmen adaylarmm fen ögretimi bakkendaki görüsleri, 7.Ulusal Fen Bilimleri ve Matematik Eğitimi Kongresi, Ankara

Hewett, V. M. (2001). Examining the Reggio Emilia approach to early childhood Education. Early Childhood Education Journal,29,2, 95 -100.

Huang,Y.P. \&Flores, L.Y.(2011). Exploring the validity of the problem solving inventory with mexican american high school students. Journal of Career Assessment, 19(4) 431-441.

Inel Ekici, D. (2014).The perceptions and views about problem solving process of pre-service science teachers.Procedia Social and Behavioral Sciences, 141(2014), 308-312.

Kallery, M.\& Psillos, D. (2001). Pre-School teachers' content knowledge in science: Their understanding of elementary science concepts and of issues raised by children's questions. International Journal Of Early Years Education, 9 (3), 165-179. 
Kallery, M. (2004).Early years teachers' late concerns and perceived needs in science: an exploratory study.European Journal of Teacher Education, 27(2), 147-165.

Karasar, N. (2009). Bilimsel arastırma yöntemi. Ankara: Nobel Yayın.

Kaya, B. (2008). Sosyal bilgiler ögretmen adaylarmm problem çözme ve karar verme becerilerinin ögretimine yönelike öz. yeterliklerinin değerlendirilmesi. Yayımlanmamış doktora tezi, Gazi Üniversitesi Eğitim Bilimleri Enstitüsü, Ankara.

Kefi, S., Çeliköz, N., \& Erişen, Y. (2013). Okulöncesi eğitim öğretmenlerinin temel bilimsel süreç becerilerini kullanım düzeyleri. Ë̆itim ve Öğretim Arasstırmalan Dergisi, 2(2), 300-319.

Kesgin, E. (2006). Okul öncesi eğitimi ögretmenlerinin öz-yeterlilik düzeyleri ile problem çözme yaklaşımlarm kullanma düzeyleri arasındaki ilişkinin incelenmesi (Denizli ili örneği). Yayımlanmamış yüksek lisans tezi, Pamukkale Üniversitesi Sosyal Bilimler Enstitüsü, Denizli.

Kocabaş, A. (1997). Temel eğitim 2. kademe öğrencileri için müziğe ilişkin tutum ölçeğinin geçerlik ve güvenirlik çalışması. Hacettepe Üniversitesi Eğitim Fakültesi Dergisi, 13, 141-145.

Liang, J.C. (2009). How a science education course can influence early childhood teachers attidues toward science. Asia pasific journal of research in early childhood education, 3(2), 123-143.

Lind, K. K. (2000). Exploring science in early childhood education. Delmar: Albany.

Martin, D. J. (2000). Constructing early childhood science. Albany, NY: Delmar.

Nilsson, P. (2015). Catching the moments - coteaching to stimulate science in the preschool context. Asia-Pacific Journal of Teacher Education, 43(4) 296-308. doi:10.1080/1359866X.2015.1060292

Oğuzkan, Ş. \& Oral, G. (2003). Okulöncesi eğitimi (12. Basım). İstanbul: Milli Eğitim Basımevi.

Parlakyıldız, B.,\& Aydın, F. (2004, Temmuz). Okulöncesi dönem fen eğitiminde fen ve doğa kössesinin kullanımına yönelike bir inceleme. XIII. Ulusal Eğitim Bilimleri Kurultayı, Malatya.

Sarı, H.,\&Bozgeyikli, H. (2003) Öğretmen adaylarının özel eğitime yönelik tutumlarının incelenmesi: Karşılaştırmalı bir araştırma. Selçuk Üniversitesi Sosyal Bilimler Enstitüsü Dergisi, 9,183-204

Savaşır, İ.,\& Şahin, N. H. (1997). Bilişsel-davranış̧ terapilerdedeğerlendirme: Sık kullanulan ölçekler. Ankara: Türk Psikologlar Derneği Yayınları.

Seefeldt, C. \& Galper, A. (2002). Active experience for acive children sicence. Uupper Saddle River, NJ: Prentice Hall.

Shrigley, R.L., Koballa, T. R. \& Simpson, R.D. (1988). Defining attitude for science educators. Journal of Research in Science Teaching. 25(8), 659-678.Sığırtmaç, A., \& Özbek, S. (2011). Okulöncesi öğretmenlerinin fen eğitimine ilişkin görüşleri ve uygulamalarının incelenmesi. Education Sciences, 6(1), 1039-1056. 
Karışan, D., Bilican, K., \& Şenler, B. (2017). Bilimsel Sorgulama Hakkında Görüş Anketi: Türkçeye Uyarlama, Geçerlik Ve Güvenirlik Çalışması. Inonu University Journal of the Faculty of Education (INUJFE), 18(1).

Simpson, R.D., Koballa, T.R. Jr., Oliver, J.S., \& Crawley, F.E. (1994).Handbook of research on science teaching and learning. In D. White (Eds). Research on the affective dimension of science learning(pp. 211-235). . New York: MacMillan Publishing Company.

Şahin, N., Şahin, N. H. \& Heppner, P. P.(1993). Psychometric proporties of the problem solving inventory in group of Turkish university students. Cognitive Therapy and Research,17(4), 379396.

Taylan, S. (1990). Heppnerin problem çö:me envanterinin uyarlama, güvenirlik ve geçerlik çallşmalar. Yayınlanmamış Yüksek Lisans Tezi, Ankara Üniversitesi Sosyal Bilimler Enstitüsü, Ankara.

Tuğrul, B.A. (1993). Okul öncesi dönemde etkin ögretmen modeli.9. Ya-pa okul öncesi eğitimi ve yaygınlaştırılması semineri, Ankara, Seminer Kitabı. İstanbul: Ya-pa Yayınları, İstanbul.

Udeani,U. \& Adeyemo,S.A.(2011). The relationship among teachers' problem solving abilities, student's learning styles and students' achievement in biology. International Journal of Educational Research and Technology,2(1),82-87.

Van Aalderen-Smeets, S., van der Molen, J., \& Asma, L. (2012). Primary teachers' attitudes toward science: A new theoretical framework. Science Education, 96, 158- 182. doi:10.1002/sce.20467. 